\title{
Collection and 28-Day Storage of Human Placental Blood
}

\author{
ELLEN M. BIFANO, ROBERT A. DRACKER, KEVIN LORAH, AND ANURADHA PALIT \\ Departments of Pediatrics and Pathology, State University of New York Health Science Center, \\ Syracuse, New York 13210
}

\section{ABSTRACT}

\begin{abstract}
Placental blood was harvested using a novel collection system into packs containing citrate-phosphate-dextroseadenine and then stored for $28 \mathrm{~d}$. Before and during storage, sterility, adequacy of anticoagulation, blood chemistry, and red cell viability were assessed weekly. The average volume of blood collected was $65 \mathrm{~mL}$ (range 30 $110 \mathrm{~mL}$ ) with a 0.42 hemocrit once diluted in anticoagulant. All blood culture specimens were sterile at collection and during storage. Adequate anticoagulation (activated partial thromboplastin time $>90 \mathrm{~s}$ ) on the day of collection was achieved in 15 specimens, all less than $65 \mathrm{~mL}$ of blood volume. Ten specimens, in blood volumes ranging from 65 to $110 \mathrm{~mL}$, had mean activated partial thromboplastin time values of $65.3 \pm 10.2 \mathrm{~s}$. Activated partial thromboplastin time values for all 25 specimens at $1,2,3$, and $4 \mathrm{wk}$ storage
\end{abstract}

In the United States, more than 40000 VLBW infants are born each year, many of whom are critically ill and require care in neonatal intensive care facilities. The majority of these infants will require one or more homologous blood transfusions during the first month of life. These transfusions are given to replace losses due to diagnostic sampling and to treat the physiologic decline in $\mathrm{Hb}$ concentration designated the anemia of prematurity (1-3). Studies have shown that VLBW infants will receive approximately $50 \mathrm{~mL}$ of blood per $\mathrm{kg}$ from as many as eight to 10 adult donors during the first month of life (1, 3 , 4). However, recent data suggest that changes in transfusion practices for neonates may reduce donor exposure $(5,6)$. Although red cell transfusion is a valuable part of care, the use of adult donor blood poses risks for these infants including the transmission of viral agents such as non- $A$ and non-B hepatitis, cytomegalovirus, and human immunodeficiency virus $(1,7,8)$. Furthermore, graft versus host disease has been reported after homologous transfusions in neonates (8-11).

Received July 31, 1992; accepted January 26, 1994.

Correspondence and reprint requests: Ellen M. Bifano, M.D., SUNY Health Science Center, 750 E. Adams St., Syracuse, NY 13210.

Supported by Cutter Biologicals, Miles, Inc. were $>90 \mathrm{~s}$, presumably because of the decline in labile clotting factors after $24 \mathrm{~h}$ of storage. Hematocrit, red cell ATP, and red cell shape were maintained during storage. As expected, red cell 2,3-diphosphoglycerate declined and potassium levels rose significantly but were not different than levels reported for adult cells similarly preserved. Based on our results, it appears that placental blood represents a potential source of autologous transfusion for the sick neonate over the first month of life. (Pediatr Res 36: 90-94, 1994)

Abbreviations
APTT, activated partial thromboplastin time
CPDA, citrate-phosphate-dextrose-adenine
2,3-DPG, 2,3-diphosphoglycerate
VLBW, very low birth weight

The benefits of autologous transfusion in adults have been demonstrated to include elimination of the risks of transfusion-transmitted viral diseases, allogenic sensitization to red cell antigens, and posttransfusion graft versus host disease $(12,13)$. Blood for autologous transfusion in adults is either predeposited for elective surgery, hemodiluted preoperatively and reinfused after surgery, or salvaged during surgery for retransfusion $(12$, 13). The demonstration of the effectiveness and safety of such practices for adults has led to the use of autologous blood for select pediatric patients (14).

The placenta, containing a reservoir of the infant's blood, represents an ideal source of autologous blood for the newborn. Over the past $10 \mathrm{y}$, it has become acceptable practice to use autologous placental blood immediately after birth to replace volume losses in newborns (15). Studies have shown the bacteriologic safety and adequacy of anticoagulation of placental blood harvested into heparinized containers for this immediate use (1618). However, because this technique has not been standardized, it has not gained widespread acceptance among clinicians. The feasibility of storing autologous placental blood for transfusion in newborns has been explored by other investigators (19-22). In these studies, placental blood was collected into syringes containing anticoagu- 
lant and then either stored in collection bags or in test tubes for up to $21 \mathrm{~d}$. In the present study, we report a novel system for the closed, aseptic collection and 28-d storage of residual autologous blood from the postnatal placenta.

\section{METHODS}

Umbilical blood was collected from only term or nearterm placentas after delivery by cesarean section or vaginal delivery at Crouse Irving Memorial Hospital in Syracuse, New York. Only placentas delivered after less than $6 \mathrm{~h}$ of membrane rupture and with no evidence of chorioamnionitis were used.

Collection technique. Immediately after delivery and umbilical cord separation, the placenta and umbilical stump were placed onto a sterile field for inspection and vessel access determination. A sterile $200-\mathrm{mL}$ polyvinyl chloride collection bag (Cutter Biological, Miles Inc., Covina, CA) was placed into an airtight acrylic vacuum chamber, with the incoming phlebotomy line and the outgoing aliquot line exiting through two holes in the gasketted top of the chamber (Fig. 1). The umbilical stump was cleansed using a modification of the procedure for venipuncture outlined in the Technical Manual of the American Association of Blood Banks (23). First, the umbilical stump was scrubbed with povidone-iodine scrub for $15 \mathrm{~s}$. Then the stump was prepared two times with $70 \%$ isopropyl alcohol and $20 \%$ povidone-iodine swabs, allowing $30 \mathrm{~s}$ for the povidone-iodine to dry. After the umbilical vein was punctured at the juncture of the umbilical cord and placenta, the wall suction was turned on to develop a negative pressure of up to $50 \mathrm{~cm}$ within the chamber, thereby drawing the placental blood into the collection bag. Each primary bag contained $14 \mathrm{~mL}$ of CPDA-1 anticoagulant. No umbilical vein was entered more than once. The collection bag was intermittently agitated during the collection period of no more than 4 min. No limit was placed on the volume of blood harvested during the collection period.

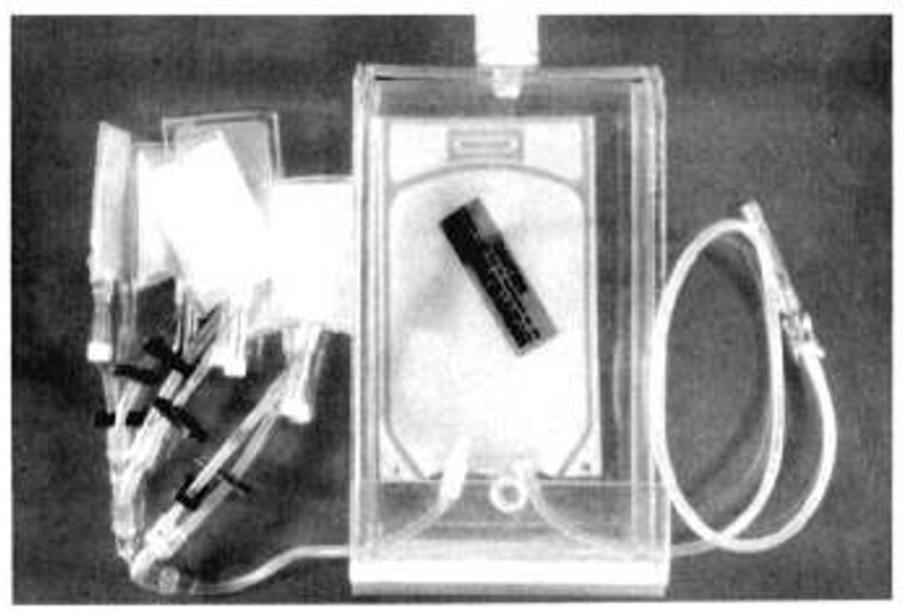

Figure 1. Photograph of placental blood collection system including plexiglass chamber, primary bag, and satellite bags.
Upon completion of the phlebotomy, the vacuum was turned off, the tubing was clamped, and the phlebotomy needle and tubing were separated from the collection bag. The tared bag was weighed to determine the blood volume collected. Surface cultures of the umbilical cord phlebotomy site were performed both before and after site preparation.

To avoid contamination when removing blood aliquots from the primary bag for either testing or potential transfusion, an integrally attached system of six satellite bags of $20-\mathrm{mL}$ volume was devised. Placental blood was stored in the primary bag at $4^{\circ} \mathrm{C}$ until the day of testing, when one of the satellite bags was filled. Aliquots were removed from each satellite bag by needle and syringe through an injection port. Samples were taken before storage and at weekly intervals during $28 \mathrm{~d}$ of storage for the following laboratory studies.

Bacteriologic studies. Surface cultures of the umbilical cord at the phlebotomy site were performed using a swab touch preparation technique both before and after preparation of the cord. The touch preparations were plated immediately on blood agar plates and read at 24 and $48 \mathrm{~h}$. Blood cultures of the stored blood were performed by placing $2 \mathrm{~mL}$ of blood (recommended volume) into Bactec NR660 aerobic/anaerobic 50-mL pediatric blood culture bottles (Becton Dickinson, Sparks, MD). Cultures were assessed daily for $7 \mathrm{~d}$ after inoculation for the presence of bacterial growth.

Coagulation studies. APTT were determined using Actin FSL (Sigma Diagnostics, St. Louis, MO) and calcium chloride on an Electra 1000C automated coagulation timer (Medical Laboratories Automation, Inc., Pleasantville, NY) Adequate anticoagulation was defined as an APTT $>90 \mathrm{~s} \mathrm{(23).} \mathrm{No} \mathrm{additional} \mathrm{anticoagulant} \mathrm{was} \mathrm{added}$ to the blood specimens after sampling from the blood units.

Chemistry studies. Potassium and glucose tests were performed on a Hitachi 736 automated blood chemistry analyzer (Boehringer-Mannheim, Indianapolis, IN). Blood $\mathrm{pH}$ determinations were performed on a Radiometer ABL 3 (Radiometer, Copenhagen, Denmark).

Red cell studies. We used the standards of the American Association of Blood Banks for viability and function of adult cells stored under similar conditions to evaluate fetal cell storage characteristics (23). Studies were performed on fetal blood only and compared with reported values for adult blood stored similarly. These characteristics included measurement of blood counts, intracellular ATP, 2,3-DPG, percent hemolysis, and red cell morphology. Complete blood counts were performed on a Technicon $\mathrm{H}-1$ automated hematology instrument (Technicon Instruments, Corp., Tarrytown, NY). Intracellular ATP was estimated spectrophotometrically by measuring the change in absorbance at $340 \mathrm{~nm}$ caused by the oxidation of NADH to NAD by glyceraldehyde phosphate dehydrogenase using the methods specified in the commercial kit (Sigma Kit 336-UV, Sigma Chemical Co., St. Louis, MO). The effects of storage on oxygen-releasing 
capacity were assessed by measuring changes in red cell 2,3-DPG. Levels of 2,3-DPG was quantified spectrophotometrically by measuring the decrease in absorbance at $340 \mathrm{~nm}$ caused by the oxidation of NADH to NAD according to the methods specified in the commercial kit (Sigma 35-UV, Sigma Chemical Co., St. Louis, MO). Blood samples were assayed for the presence of supernatant $\mathrm{Hb}$ by the cyanomethhemoglobin method. Supernatant absorbance was measured at $540 \mathrm{~nm}$ in the presence of Drabkins reagent and was computed as the percentage of complete hemolysis for packed cells. For microscopy, a red cell smear was prepared on glass slides using hematoxylin-eosin stain. The percent of echinocytes was estimated as the percentage of cells from a total count of at least 200 that were echinocytes under light microscopy (50X-oil).

\section{RESULTS}

Collection data. Thirty-one umbilical blood collections were performed on the placentas from infants delivered by cesarean section $(n=26)$ or vaginally $(n=5)$ from August 1990 through May 1991 at Crouse Irving Memorial Hospital. The mean blood volume aspirated was 65 $\mathrm{mL}$ (range, $30-110 \mathrm{~mL}$ ). Table 1 shows the calculated amount of autologous blood available for transfusion if the cells were prepared as packed red blood cells (hematocrit 0.80 ) stratified in volumes of $10-\mathrm{mL}$ aliquots.

Bacteriologic data. Surface cultures of the phlebotomy sites were positive for Staphylococcus epidermidis in two of 25 samples. These two positive specimens were taken from vaginally delivered placentas. All surface cultures taken after cord preparation, as well as blood cultures obtained weekly from stored units, remained negative for 4 wk.

Red cell studies. The mean hematocrit of the collected blood was 0.42 . The hematocrits were lower than those of the cord blood specimens because of hemodilution from the addition of preservative to collection bags.

No significant decline in hematocrit values or substantial increase in hemolysis was observed in units stored for $28 \mathrm{~d}$ (Table 2). Red blood cell ATP levels showed a mild decline, and over the same storage period there was a marked reduction in 2,3-DPG levels. No significant

Table 1. Placental blood volume stratified by volume recovered adjusted to hematocrit of $0.80^{*}$

\begin{tabular}{cc}
\hline $\begin{array}{c}\text { Stratified blood } \\
\text { volume }(\mathrm{mL})\end{array}$ & Number \\
\hline $1-10$ & 0 \\
$11-20$ & 1 \\
$21-31$ & 1 \\
$31-40$ & 15 \\
$41-50$ & 9 \\
$51-60$ & 4 \\
$61-70$ & 1 \\
\hline
\end{tabular}

* Volumes were calculated based on the volume and hematocrits of the collected placental blood sample.
Table 2. Changes in red cell values in stored placental blood*

\begin{tabular}{ccccc}
\hline Days & $\begin{array}{c}\text { Hematocrit } \\
(\%)\end{array}$ & $\begin{array}{c}\text { Hemolysis } \\
(\%)\end{array}$ & $\begin{array}{c}\text { ATP } \\
(\mu \mathrm{mol} / \mathrm{g} \mathrm{Hb})\end{array}$ & $\begin{array}{c}2,3-\mathrm{DPG} \\
(\mu \mathrm{mol} / \mathrm{g} \mathrm{Hb})\end{array}$ \\
\hline 0 & $42 \pm 2$ & $0.28 \pm 0.07$ & $4.32 \pm 0.58$ & $13.30 \pm 1.00$ \\
7 & $44 \pm 2$ & $0.32 \pm 0.05$ & $3.96 \pm 0.36$ & $6.68 \pm 0.76$ \\
14 & $42 \pm 3$ & $0.34 \pm 0.05$ & $4.00 \pm 0.77$ & $3.67 \pm 1.10$ \\
21 & $41 \pm 1$ & $0.36 \pm 0.06$ & $3.86 \pm 0.79$ & $2.03 \pm 0.75$ \\
28 & $41 \pm 2$ & $0.39 \pm 0.05$ & $3.46 \pm 0.56$ & $1.31 \pm 0.28$ \\
\hline
\end{tabular}

* All values are mean $\pm \mathrm{SD}$.

change in red cell morphology, determined as the percentage of echinocytes was observed.

Coagulation studies. Adequate anticoagulation (APTT $>90 \mathrm{~s}$ ) on the day of collection was achieved in 15 specimens, all less than $65 \mathrm{~mL}$ of blood volume. Ten specimens, in blood volumes ranging from 65 to $110 \mathrm{~mL}$, had mean APTT values of $65.3 \pm 10.2 \mathrm{~s}$. APTT values for all 25 specimens at $1,2,3$, and $4 \mathrm{wk}$ of storage were $>90$ s, presumably because of the decline in labile clotting factors after $24 \mathrm{~h}$ of storage. There were no clots or clumps apparent on any of the specimens.

Chemistry data. As can be seen in Table 3, a fall in plasma glucose was accompanied by a decline in extracellular $\mathrm{pH}$ resulting from metabolic glycolysis by red cells during storage. Plasma $\mathrm{pH}$ never fell below 6.39. Extracellular potassium values rose to a maximal mean value of $32 \pm 6 \mathrm{mmol} / \mathrm{L}$.

\section{DISCUSSION}

The majority of premature infants receive one or more red blood cell transfusions during hospitalization (3). A retrospective review in our neonatal intensive care unit found that $55 \%$ of VLBW infants received at least one red cell transfusion, and $86 \%$ of these infants required more than three transfusions during the first month of life (24). Whereas the risk for an individual exposure is small, the cumulative risks are not inconsequential and are a cause of great parental anxiety $(1,3)$. Therefore, the development of strategies to avoid donor blood transfusions in this population seems warranted.

Autologous fetal blood from the placenta has been used for volume resuscitation of the newborn in the delivery room (16-18). Paxson (16) and Golden et al. $(17,18)$ demonstrated that placental blood could be collected into heparinized containers for use within the first $12 \mathrm{~h}$ of life.

Table 3. Changes in glucose, potassium, and $\mathrm{pH}$ in stored placental blood*

\begin{tabular}{cccc}
\hline Days & $\begin{array}{c}\text { Glucose } \\
(\mathrm{mmol} / \mathrm{L})\end{array}$ & $\begin{array}{c}\text { Potassium } \\
(\mathrm{mmol} / \mathrm{L})\end{array}$ & $\mathrm{pH}$ \\
\hline 0 & $29.1 \pm 3.7$ & $8.2 \pm 3.4$ & $6.85 \pm 0.14$ \\
7 & $27.3 \pm 4.2$ & $19.2 \pm 6.0$ & $6.72 \pm 0.12$ \\
14 & $23.7 \pm 4.4$ & $25.2 \pm 5.1$ & $6.67 \pm 0.11$ \\
21 & $20.8 \pm 3.6$ & $28.4 \pm 5.6$ & $6.58 \pm 0.09$ \\
28 & $18.4 \pm 4.7$ & $32.0 \pm 5.9$ & $6.51 \pm 0.12$ \\
\hline
\end{tabular}

* All values are mean \pm SD. 
Other investigators have extended these observations to demonstrate the feasibility of the short-term storage of placental blood (19-22).

Our study was undertaken to establish the feasibility and safety of banking placental blood using a new "closed" system of blood collection. We collected 30$100 \mathrm{~mL}$ of placental blood from 31 term deliveries. These volumes of placental blood, if prepared as packed red cells (hematocrit 0.80 ), would be sufficient to meet the transfusion needs of many VLBW neonates (4). However, it is yet to be determined whether adequate volumes of placental blood can be harvested from the placentas after preterm deliveries. Anderson et al. (22), using a needle-syringe technique, collected enough placental blood from preterm deliveries to provide at least one transfusion for $87 \%$ of infants studied. Perhaps for those infants from whom smaller volumes of blood are collected, transfusion with autologous placental blood combined with the early initiation of recombinant erythropoietin therapy may prove to be a useful strategy to avoid donor transfusions.

Our preliminary results suggest that adequate anticoagulation and sterility can be achieved using banked placental blood. An APTT $>90 \mathrm{~s}$ was achieved with 14 $\mathrm{mL}$ of CPDA in the primary collection bag for blood volumes of $<65 \mathrm{~mL}$. Subsequent studies with increased volumes of anticoagulant will determine the optimal amount of anticoagulant for larger blood volumes.

A recent editorial on the practice of using banked autologous blood for transfusion elaborated a number of important safety issues including bacterial contamination (25). We achieved sufficient decontamination after povidone iodine and alcohol preparation of the phlebotomy site, inasmuch as all surface cultures were negative. Furthermore, we observed no bacterial contamination in any units throughout the 28 -d storage period. Prior studies investigating the bacteriologic safety of autologous placental blood have used a needle-syringe technique for collection with subsequent transfer into storage bags (21, 22). Horn et al. (21) found no growth of bacteria or fungi in 33 consecutive placental blood collections monitored during $2 \mathrm{wk}$ of storage, whereas Anderson et al. (22) demonstrated that $12 \%$ of blood cultures were positive for bacteria. However, in this study, blood was collected after multiple venipunctures from undelivered placentas. Our system minimizes contamination risk because collection time is limited after a single umbilical vein puncture and the blood is harvested directly into the collection bag, which is never reentered once collection is complete. Although our results suggest that umbilical phlebotomy can be performed aseptically, substantially more experience needs to be gained to assess the influence of perinatal variables such as duration of membrane rupture greater than $6 \mathrm{~h}$ and mode of delivery on bacteriologic safety.

Although we did not perform concomitant controls on adult blood, our results showed the storage characteristics of fetal blood were similar to those reported for adult blood (23). There were no declines in hematocrit values, minimal hemolysis, and elevations in plasma potassium concentrations comparable to those reported for adult red cells stored in CPDA over the same time period (23). During $4 \mathrm{wk}$ of storage, red cells from placentas maintained $80 \%$ of prestorage ATP levels, which agrees with prior studies of the storage characteristics of fetal blood $(19,21)$. These ATP levels correlate with acceptable posttransfusion red cell survival for adult blood (23). The marked decline in 2,3-DPG levels seen after storage in the fetal red cells is similar to what is reported for red cells from adults and previous reports of fetal blood $(19,21)$. After transfusion, adult red cell 2,3-DPG levels recover to prestorage values (23). However, no information is available regarding posttransfusion 2,3-DPG levels in red cells from newborns.

Despite our results and those of others showing that fetal cells behave satisfactorily during storage, it has been cautioned that, once transfused, the unique biochemical and morphologic features of these cells may yet render them an unsatisfactory transfusion product (25). Those features that might affect their use include a predominance of $\mathrm{Hb} \mathrm{F}$ with a higher oxygen affinity, a shortened in vivo life-span, increased proportion of morphologic abnormalities, greater susceptibility to lipid peroxidation, altered membrane lipid fluidity, and more labile ATP levels (26-29). Ultimately, clinical studies evaluating in vivo posttransfusion red cell survival will determine whether transfused autologous placental blood is as satisfactory as donor blood.

In addition to the banking of autologous placental blood, other suggested strategies to minimize the number of transfusions and donor blood exposures include the development of novel blood banking techniques, the initiation of new obstetrical procedures, and the use of recombinant erythropoietin therapy (3). Blood banking strategies designed to accommodate the needs of the small infant have addressed problems related to handling of small blood volumes, limiting donor exposure, and minimizing blood wastage (30-34). Holland et al. (35) have suggested that delayed clamping of the umbilical cord decreases transfusion requirements during the first week of life. However, controlled studies have not demonstrated the efficacy and safety of this practice for premature infants, in whom the risks of delayed resuscitation and intraventricular hemorrhage due to sudden increase in intravascular volume have to be considered. Pilot studies $(36,37)$ suggest that treatment of premature infants with recombinant erythropoietin will reduce transfusion needs during the anemia of prematurity (late anemia). However, this therapy would not be useful in the first 2 wk of life, when the greatest number of transfusions occur. Thus, despite these strategies, no single approach has been systematically shown to eliminate the need for homologous blood transfusions for most VLBW premature infants. Therefore, autologous fetal blood transfusion offers a reasonable alternative to be explored for use in the newborn. 


\section{REFERENCES}

1. Strauss RG 1991 Transfusion therapy in neonates. Am J Dis Child 145:904-911

2. Holland BM, Wardrop CAJ 1991 Anaemias of the preterm infant. In: Turner TL (ed) Perinatal Haematological Problems. John Wiley and Sons, New York, pp 121-135

3. Strauss RG 1991 Neonatal anemia: pathophysiology and treatment. In: Wilson SM, Levitt JS, Strauss RG (eds) Improved Transfusion Practice for Pediatric Patients. American Association of Blood Banks, Arlington, VA, pp 1-17

4. Obladen M, Sachsenager M, Stahnke M 1988 Blood sampling in very low birthweight infants receiving different levels of intensive care. Eur $\mathrm{J}$ Pediatr 147:399-404

5. Levy GJ, Strauss RG, Hume H, Schloz L, Albanese MA, Blazina J, Werner A, Sotelo-Avila C, Barrasso C, Blachette V, Warkentin PI, Pepkowitz S, Mauer AM 1993 National survey of neonatal transfusion practices: I. red blood cell therapy. Pediatr 91:523-529

6. Goodstein MH, Locke RG, Wlodarczyk D, Goldsmith LS, Rubenstein SD, Herman JH 1993 Comparison of two preservation solutions for erythrocyte transfusions in newborn infants. J Pediatr 123:783-788

7. Griffin MP, O'Shea M, Brazy JE, Koepke J, Klein D, Malloy C, Wilfert CM 1988 Cytomegalovirus infection in a neonatal intensive care unit. Am J Dis Child 142:1188-1193

8. Blajchman MA, Sheridan D, Rawls WE 1984 Risks associated with blood transfusion in newborn infants. Clin Perinatol 11:403-415

9. Brubaker DB 1986 Transfusion-associated graft-versus-host disease. Hum Pathol 17:1085-1088

10. Sanders MR, Graeber JE 1990 Posttranfusion graft-versus-host disease in infancy. J Pediatr 117:159-161

11. Lang DL, Valerie CR 1977 Hazards of blood transfusion. Adv Pediatr 24:511-538

12. Council on Scientific Affairs 1986 Autologous blood transfusions. JAMA 256:2378-2380

13. Zuck TF, Corey PM 1990 Autologous transfusion practice. Controversies about current practices and real needs. Vox Sang 58:234-253

14. DePalma L, Luban NLC 1990 Autologous blood transfusion in pediatrics. Pediatrics 85:125-128

15. Bloom RS 1992 Delivery room resuscitation of the newborn. In: Fanaroff AA, Martin RJ (eds) Neonatal-Perinatal Medicine. CV Mosby Co, St. Louis, pp 301-324

16. Paxson CL 1979 Collection and use of autologous fetal blood. Am J Obstet Gynecol 134:708-710

17. Golden SM, Petit N, Mapes T, Davis S, Monaghan WP 1984 Bacteriologic assessment of autologous cord blood for neonatal transfusion. Am J Obstet Gynecol 149:907-908

18. Golden SM, O'Brien WF, Lissner C, Cefalo RC, Schumacher H, Stass S 1980 Hematologic and bacteriologic assessment of autologous cord blood for neonatal transfusions. J Pediatr 97:810-812
19. Brandes JM, Roth EF, Berk PD, Bottone E, Milano CT, Sarkozi L, Zaroulis G 1983 Collection and preservation of human placental blood. Transfusion 23:325-327

20. Abel M, Elsinger W, de Gregorio G, Peukert W 1985 Unteruchungen zur transfusions medizinischen Validitat von autologen plazentablut. Infusionstherapie 12:197-200

21. Horn S, Mazor D, Zimora E, Meyerstein N 1987 Storage-induced changes in newborn red cells. Transfusion 27:411-414

22. Anderson S, Fangman J, Wager G, Aden D 1992 Retrieval of placental blood from the umbilical vein to determine volume, sterility, and presence of clot formation. Am J Dis Child 146:36-39

23. Walker RH (ed) 1990 Technical Manual of the American Association of Blood Banks, Arlington, VA, pp 37-57

24. Bifano E, Palit A, Lorah K, Dracker R 1991 Neonatal autologous transfusion: a potential form of hemotherapy. Pediatr Res 29:273(abstr)

25. Strauss RG 1992 Autologous transfusions for neonates using placental blood: a cautionary note. Am J Dis Child 146:21-22

26. Coulombel L, Tchernia G, Feo C, Mohandas N 1982 Echinocytic sensitivity and deformability of human newborn red cells. Biol Neonate 42:284-290

27. Pearson HA 1967 Life-span of the fetal red blood cell. J Pediatr 70:166-171

28. Stockman JA, Oski FA 1978 Erythrocytes of the human neonate. Curr Top Hematol 1:193-232

29. Crespo LM, Bifano, EM, Freedman JC 1988 Membrane lipid fluidity and filterability of red blood cells from adults and newborns. Pediatr Res 24:433437

30. Blankenship WJ, Goetzman BW, Gross S, Hattersley PG 1975 A walking donor program for an intensive care nursery. J Pediatr 86:583-585

31. Strauss RG, Crawford CF, Elbert C, Floss AM, Liesch M 1986 Sterility and quality of blood dispensed in syringes for infants. Transfusion 26:163-166

32. Hakanson DO, Clarke DA 1981 Efficient blood use in a neonatal intensive care unit: the "cow" technique. Am J Dis Child 135:1145-1146

33. Patten E, Robbins M, Vincent J, Richardson J, Hokanson J 1991 Use of red cells older than five days for neonatal transfusion. J Perinatol 11:37-40

34. Luban NLC, Strauss RG, Hume HA 1991 Commentary on the safety of red cells preserved in extended storage media for neonatal transfusions. Transfusion 31:229-235

35. Holland BM, Wardrop CAJ 1991 In: Turner TL (ed) Perinatal Haematological Problems. John Wiley and Son Inc, New York, pp 121-135

36. Halperin DS, Wacher P, Lacourt G, Felix M, Babel JF, Aapro M, Wyss M 1990 Effects of recombinant human erythropoietin in infants with the anemia of prematurity: a pilot study. J Pediatr 116:779-786

37. Shannon KM, Mentzer WC, Abels RI, Wertz M, Thayer-Moriyama J, Li WI, Thompson D, Decelle S, Phibbs RH 1991 Enhancement of erythropoiesis by recombinant human erythropoietin in low birthweight infants: a pilot study. $J$ Pediatr 118:586-592 